\title{
STUDI KOMPARATIF MODEL PEMBELAJARAN THINK PAIR SQUARE DAN THINK PAIR SHARE TERHADAP MOTIVASI DAN HASIL BELAJAR SISWA MAPEL TIK KELAS X SMA N 1 SUKASADA
}

\author{
Putu Deli Januartini'), Ketut Agustini2), I Gede Partha Sindu3) \\ ${ }^{1}$ Fakultas Teknik dan Kejuruan, Universitas Pendidikan Ganesha (penulis 1) \\ email: 1215051009@undiksha.ac.id \\ ${ }^{2}$ Fakultas Teknik dan Kejuruan, Universitas Pendidikan Ganesha (penulis 2) \\ email: ketutagustini@undiksha.ac.id \\ ${ }^{3}$ Fakultas Teknik dan Kejuruan, Universitas Pendidikan Ganesha (penulis 3) \\ email: partha.sindu@undiksha.ac.id
}

\begin{abstract}
Abstrak
Tujuan penelitian ini untuk mengetahui (1) pengaruh signifikan penggunaan model pembelajaran Think Pair Square dan Think Pair Share terhadap hasil belajar siswa, (2) hasil belajar yang lebih baik antara model pembelajaran Think Pair Square atau Think Pair Share, (3) motivasi belajar siswa, (4) respon siswa.

Jenis penelitian ini adalah eksperimen semu dengan rancangan Post Test Only Control Group Design. Populasi penelitian ini adalah seluruh siswa kelas X. Sampel dalam penelitian ini adalah kelas X1 dengan model Think Pair Square, kelas X3 dengan model Think Pair Share dan X5 dengan model Direct Instruction.

Data hasil belajar dianalisis melalui uji prasyarat dengan hasil ketiga kelompok berdistribusi normal dan homogen serta uji hipotesis menggunakan Anova Satu Jalur dengan hasil terdapat pengaruh yang signifikan penggunaan model pembelajaran Think Pair Square, Think Pair Share dan Direct Instruction. Kemudian uji lanjut $t$ Scheffe dengan hasil terdapat perbedaan hasil belajar penggunaan model pembelajaran Think Pair Square, Think Pair Share dan Direct Instruction. Dilihat dari rata-rata hasil belajar maka disimpulkan model Think Pair Square lebih baik dengan hasil belajar lebih tinggi. Hasil analisis angket Think Pair Square diketahui respon sangat positif dan tingkat motivasi belajar sangat tinggi, Think Pair Share diketahui respon positif dan tingkat motivasi belajar sangat tinggi.
\end{abstract}

Kata kunci: Think Pair Square, Think Pair Share, Direct Instruction, hasil belajar, motivasi belajar, dan respon siswa.

\footnotetext{
Abstract

The purpose of this study were to determine (1) the significant influence of the application of think pair square and think pair share learning model on student's learning achievement, (2) better learning achievement between think pair square and think pair share learning model, (3) student's motivation, (4) the student's responses.

The research was a quasi-experimental design experiment with post test only control group design. The population of study was all the students in grade X. The sample were as X1 class with the application of Think Pair Square learning model, X3 class with the application of Think Pair Share learning model, and X5 class with the application of Direct Instruction learning model.

The data was collected by cognitive and psychomotor tests. The student's learning achievement were analyzed by the prerequisite test with the results of the three groups at normal distribution and homogenous, and the hypothesis tested by One Way Anova which means there is a significant effect on the application of think pair square, think pair share, and direct instruction learning models. Then it was conducted a further test $t$-Scheffe with the results there are differences in the learning achievement between think pair square, think pair share, and direct instruction learning models. According to the average result we made a conclusion that Think Pair Square was better learning models with higher student's learning achievement. The questionnaires results shows that Think Pair Square was very high positive
} 
response and very high learning motivation, Think Pair Share was high positive response and very high learning motivation.

Keywords : Think Pair Square, Think Pair Share, Direct Instruction, learning achievement, learning motivation, and student response.

\section{PENDAHULUAN}

Pendidikan menurut Bapak Ki Hajar Dewantara adalah daya upaya untuk memajukan budi pekerti (karakter, kekuatan batin), pikiran (intellect) dan jasmani anak-anak selaras dengan alam dan masyarakatnya. Maksud dari pernyataan tersebut yaitu pendidikan bertujuan dalam menuntun segala kekuatan yang ada pada anak-anak tersebut. Kelak nantinya mereka sebagai manusia dan sebagai anggota masyarakat dapat meraih kesesuksesan dan kebahagiaan yang setinggi-tingginya. Terdapat banyak satuan pendidikan dalam masing-masing jalur pendidikan yang siap mencerdaskan kehidupan bangsa sesuai dengan pembukaan undang-undang 1945. Seluruh pemberi pendidikan dalam satuan pendidikan memiliki tanggung jawab besar dalam mendidik peserta didik untuk menguasai ilmu pengetahuan yang diberikan. Guru dalam hal ini memegang peranan penting dalam proses pendidikan. Pendidikan merupakan wahana untuk meningkatkan dan mengembangkan kualitas sumber daya manusia. Menurut Trianto, salah satu masalah pokok dalam pembelajaran pada pendidikan formal (sekolah) dewasa ini adalah masih rendahnya daya serap peserta didik. Hal ini nampak dari rerata hasil belajar peserta didik yang senantiasa masih sangat memprihatinkan. Prestasi ini tentunya merupakan hasil kondisi pembelajaran yang masih bersifat konvensional dan tidak menyentuh ranah dimensi peserta didik itu sendiri (Trianto, 2009).

Pendapat tersebut dapat dibuktikan dengan hasil pengamatan terhadap proses pembelajaran khususnya mata pelajaran TIK (Teknologi Informasi dan Komunikasi) kelas $X$ di SMA $N$ Sukasada. Selama proses PPL-Real di sekolah tersebut, dilihat adanya permasalahan prestasi dan motivasi belajar siswa. Berdasarkan hasil analisis angket yang disebar, terdapat 62 dari 101 siswa yang kurang mengerti dengan materi yang hanya disampaikan oleh guru. Selain itu, berdasarkan hasil observasi langsung dan analisis angket yang disebar kepada seluruh siswa kelas $\mathrm{X}$, adanya rasa jenuh yang sering dirasakan siswa ketika mengikuti proses pembelajaran yang berpusat pada guru. Guru yang mengajar juga menyampaikan bahwa siswa merasa bosan dan mengantuk jika mendengarkan guru menjelaskan materi di kelas. Rasa jenuh, bosan dan mengantuk ketika proses pembelajaran tentu saja menjadikan konsentrasi siswa mulai melemah di dalam kelas. Permasalahan tersebut kemudian mempengaruhi hasil belajar siswa yang tergolong rendah. Dilihat dari rata-rata hasil nilai UTS (Ulangan Tengah Semester) kelas $X$ dan XI SMA N 1 Sukasada yang masih tergolong rendah. Kemudian pemilihan model pembelajaran juga sangat mempengaruhi proses pembelajaran siswa. Berdasarkan hasil observasi dan wawancara langsung peneliti, guru yang mengajar kelas X SMA N 1 Sukasada paling sering menggunakan model pembelajaran Direct Instruction (Pembelajaran Langsung). Berdasarkan hasil analisis angket, terdapat 70 dari 101 siswa yang lebih suka belajar dengan teman dibandingkan belajar individu. Berdasarkan hal tersebut, seorang guru harus dapat memilih model pembelajaran yang tepat diterapkan dalam proses pembelajaran. Salah satu model pembelajaran yang dapat dipilih guru mata pelajaran TIK kelas X SMA N 1 Sukasada adalah model pembelajaran Cooperative Learning. Cooperative Learning merupakan model pembelajaran melalui kelompok kecil siswa yang saling bekerjasama dalam memaksimalkan kondisi belajar untuk mencapai tujuan belajar (Komalasari, K., 2010). Dua alasan pentingnya pembelajaran kelompok digunakan dalam pendidikan yaitu: Pertama, beberapa hasil penelitian 
membuktikan pembelajaran meningkatkan sekaligus kemampuan bahwa penggunaan prestasi belajar siswa dapat meningkatkan hubungan sosial, menumbuhkan sikap menerima kekurangan diri dan orang lain, serta dapat meningkatkan harga diri. Kedua, pembelajaran kooperatif dapat merealisasikan kebutuhan siswa dalam belajar berpikir, memecahkan masalah, dan mengintegrasikan pengetahuan dengan keterampilan (Slavin, R. E., 2009). Diantara banyaknya model pembelajaran Cooperative Learning, peneliti memilih untuk menerapkan model pembelajaran Cooperative Learning tipe Think Pair Square dan Think Pair Share. Kedua tipe model pembelajaran Cooperative Learning ini peneliti pilih karena belajar kelompok dengan berpasangan akan lebih efektif dan bermanfaat. Siswa akan menjadi lebih aktif dan fokus dalam mengerjakan tugas belajar yang diberikan guru.

Model pembelajaran kooperatif tipe Think Pair Square merupakan modifikasi dari model pembelajaran kooperatif tipe Think Pair Share dan dikembangkan oleh Spencer Kangan pada tahun 1933 (Primandari, A. H., 2010). Think Pair Square memberikan kesempatan kepada siswa mendiskusikan ide-ide mereka dan memberikan suatu pengertian bagi mereka untuk melihat cara lain dalam menyelesaikan masalah. Model pembelajaran Think Pair Square, apabila sepasang siswa tidak dapat menyelesaikan permasalahan tersebut, maka sepasang siswa yang lain dapat menjelaskan cara menjawabnya. Setelah itu, jika permasalahan yang diajukan tidak memiliki suatu jawaban benar, maka dua pasang dapat mengkombinasikan hasil mereka dan membentuk suatu jawaban yang lebih menyeluruh.

Selain model pembelajaran Cooperative Learning tipe Think Pair Square, model pembelajaran tipe Think Pair Share juga dapat diterapkan dalam proses pembelajaran. Model pembelajaran Cooperative Learning tipe Think Pair Share terdiri dari tiga tahap yaitu berpikir, berpasangan dan berbagi (Kusuma, F. W.,
\& Aisyah, M. N., 2012). Selain model pembelajaran, media juga berperan dalam kegiatan belajar mengajar. Media adalah alat bantu yang digunakan untuk mempermudah proses pembelajaran. Alat bantu mewakili sesuatu yang tidak dapat disampaikan guru lewat kata-kata atau kalimat. Media yang dapat digunakan dalam model pembelajaran Cooperative Learning tipe Think Pair Square dan Think Pair Share salah satunya adalah kartu soal. Media kartu soal adalah sarana agar siswa dapat belajar secar aktif terlibat dalam kegiatan belajar, berfikir aktif dan kritis di dalam belajar dan secara inovatif (Aisah, S., Ashari, H., \& R.Wakhid, 2013).

\section{Teori Belajar}

Pengertian belajar merupakan suatu proses perubahan yaitu perubahan tingkah laku sebagai hasil dari interaksi dengan lingkungannya dalam memenuhi kebutuhan hidupnya. Perubahan tersebut akan nyata dalam seluruh aspek tingkah laku. Belajar ialah suatu proses usaha yang dilakukan seseorang untuk memperoleh suatu perubahan tingkah laku yang baru secara keseluruhan sebagai hasil pengalamannya sendiri dalam interaksi dengan lingkungannya (Slameto, 2003). Ciri-ciri belajar adalah (1) Belajar harus memungkinkan terjadinya perubahan prilaku pada diri individu, (2) Pengalaman itu harus merupakan buah dari pengalaman, (3) Perubahan itu relatif menetap.

Teori belajar Behavioristik merupakan perubahan tingkah laku hasil interaksi antara stimulus dan respon yaitu proses manusia untuk memberikan respons tertentu berdasarkan stimulus yang datang dari luar. Teori belajar behavioristik sangat menekankan pada hasil belajar (outcome), yaitu perubahan tingkah laku yang dapat dilihat, dan tidak begitu memperhatikan apa yang terjadi di dalam otak manusia karena hal tersebut tidak dapat dilihat.

Teori Konstruktivisme ialah salah satu teori belajar, teori ini memandang bahwa siswalah yang aktif menata, merevisi pengetahuan lama yang tidak sesuai, dalam hal ini menganut pembelajaran dikelas guru membantu 
siswa menemukan fakta, konsep, prinsip dan prosedur siswa itu sendiri, bukan memberikan ceramah atau mengendalikan seluruh kegiatan kelas (Suwatra, 2007). Model pembelajaran yang termasuk dalam model pembelajaran konstruktivitik adalah Cooperative Learning (CL) dimana mengacu pada metode yang memungkinkan siswa bekerja secara bersama-sama dalam kelompok kecil untuk saling membantu di antara anggota kelompok.

\section{Model Pembelajaran Cooperative Learning}

Pembelajaran kooperatif merupakan sebuah kelompok strategi pengajaran yang melibatkan siswa bekerja secara berkolaborasi untuk mencapai tujuan bersama (Trianto, 2009). Sistem pembelajaran Cooperative Learning atau pembelajaran kooperatif merupakan sistem pengajaran yang memberi kesempatan kepada anak didik untuk bekerja sama dengan sesama siswa dalam tugas-tugas yang terstruktur. Pembelajaran kooperatif dikenal dengan pembelajaran secara berkelompok. Cooperative Learning mencakupi suatu kelompok kecil siswa yang bekerja sebagai sebuah tim untuk menyelesaikan sebuah masalah, menyelesaikan suatu tugas, atau mengerjakan sesuatu untuk mencapai tujuan bersama lainnya (Suherman, E, 2001).

Pembelajaran kooperatif merupakan salah satu model pembelajaran kelompok yang memiliki aturan-aturan tertentu. Prinsip dasar pembelajaran kooperatif adalah siswa membentuk kelompok kecil dan saling bekerjasama antar siswa untuk mencapai tujuan bersama. Dalam pembelajaran kooperatif siswa pandai dapat mengajar siswa yang kurang pandai tanpa merugikan siswa yang pandai. Siswa yang kurang pandai dapat belajar dalam suasana yang menyenangkan karena banyak teman yang membantu dan memotivasinya untuk belajar.

\section{Cooperative LearningTipe Think Pair Share}

Model pembelajaran Think Pair Share dikembangkan oleh Frank Lyman dan kawan-kawan dari Universitas Marylan (Dewi, 2014). Think Pair Share merupakan jenis pembelajaran kooperatif yang dirancang untuk mempengaruhi pola interaksi siswa. Think Pair Share dapat memungkinkan siswa untuk bekerja sendiri dan bekerja sama dengan orang lain, mengoptimalkan partisipasi siswa, dan bisa diterapkan untuk semua mata pelajaran dan tingkatan kelas. Think Pair Share (TPS) atau berpikir bepasangan berbagi adalah salah satu teknik pembelajaran kooperatif yang dirancang untuk mempengaruhi pola interaksi siswa. Selain itu, Think Pair Share merupakan suatu cara yang efektif digunakan untuk membuat variasi suasana diskusi di kelas, langkah-langkah yang digunakan dalam Think Pair Share dapat memberi siswa lebih banyak berfikir, untuk merespon dan saling membantu. Guru hanya menjelaskan secara singkat untuk melengkapi jalannya diskusi, selanjutnya siswa menjalankan tugasnya untuk menyelesaiakan masalah yang telah diberikan oleh guru (Trianto, 2010).

Model ini mengandung tiga unsur penting yaitu Think (berpikir), Pair (berpasangan) dan Share (berbagi). (1) Thinking : Pada tahap ini, guru mengajukan suatu pertanyaan atau masalah yang dikaitkan dengan pelajaran. Kemudian siswa diminta menggunakan waktu beberapa menit untuk berpikir sendiri mengenai jawaban tersebut. (2) Pairing : Selanjutnya guru meminta kepada siswa untuk berpasangan dengan siswa lain dan mendiskusikan apa yang telah mereka pikirkan. Interaksi pada tahap ini diharapkan siswa dapat berbagi jawaban/ide yang telah mereka pikirkan sebelumnya. (3) Sharing : Pada langkah akhir ini, guru meminta pasanganpasangan tersebut untuk berbagi dengan keseluruhan kelas mengenai apa yang telah mereka diskusikan dengan pasangannya.

\section{Cooperative Learning Tipe Think Pair Square}

Model pembelajaran kooperatif tipe Think Pair Square merupakan modifikasi dari model pembelajaran kooperatif tipe Think Pair Share dan dikembangkan oleh 
Spencer Kangan pada tahun $1933^{[4]}$. Dalam Think Pair Square, apabila sepasang siswa tidak dapat menyelesaikan permasalahan tersebut, maka sepasang siswa yang lain dapat menjelaskan cara menjawabnya. Setelah itu, jika permasalahan yang diajukan tidak memiliki suatu jawaban benar, maka dua pasang dapat mengkombinasikan hasil mereka dan membentuk suatu jawaban yang lebih menyeluruh. Model pembelajaran kooperatif tipe Think Pair Square (TPS) memberikan kesempatan lebih banyak kepada siswa. Model pembelajaran kooperatif tipe Think Pair Square (TPS) memberikan kesempatan lebih banyak kepada siswa. Antusias, keterlibatan, dan partisipasi siswa di dalam kelas akan mempengaruhi kualitas keseluruhan pembelajaran dan suasana kelas tersebut. Untuk memperoleh antusias, keterlibatan, dan partisipasi siswa adalah dengan diskusi. Salah satu cara mengikat siswa ke dalam diskusi adalah melalui Think Pair Square (Dorsey, Jackie, 2009).

Siswa diarahkan untuk berpikir secara individu, mengungkapkan pendapat, dan saling membantu satu sama lain melalui tahap-tahap : think (berpikir), pair (berpasangan) dan square (berbagi berempat). (1) Think: Pada tahap ini siswa bekerja secara individual sebelum bekerjasama dan berdiskusi dengan kelompoknya. Siswa diberikan untuk membaca, memahami dan memikirkan kemungkinan jawaban dari permasalahan yang diberikan oleh guru. (2) Pair : Pada tahap ini siswa diminta untuk berpasangan dengan teman lainnya dan membentuk kelompok berpasangan. Selanjutnya masing-masing siswa mengemukakan jawaban yang telah dipikirkan pada tahap think dan mendiskusikan bersama dengan pasangannya. (3) Square : Pada tahap ini, kelompok berpasangan akan bergabung dengan pasangan kelompok lainnya sehingga membentuk kelompok kecil yang terdiri 4 orang atau 2 pasang. Kedua pasangan ini mendiskusikan tugas-tugas yang belum dipahami ketika diskusi dengan pasangan sebelumnya dan menetapkan hasil akhir jawaban hasil diskusi kelompok.

\section{Hasil Belajar}

Hasil belajar adalah perubahan tingkah laku peserta didik selama dan setelah mengikuti proses belajar. Jadi, hasil belajar adalah hasil pengukuran dari penilaian usaha belajar yang dinyatakan dalam bentuk simbol, huruf maupun kalimat yang menceritakan hasil yang sudah dicapai oleh setiap anak setelah melakukan proses belajar yang diukur dengan menggunakan instrumen tes yang relevan. Hasil belajar adalah salah satu tujuan yang hendak dicapai dalam proses pembelajaran atau bisa dikatakan pencapaian yang diraih selama proses pembelajaran. Hasil yang dicapai siswa memberikan gambaran tentang posisi tingkat keberhasilan dirinya dibandingkan dengan siswa lain (Wraspana, 2013). Hasil belajar dapat diukur melalui tes yang sering dikenal dengan tes hasil belajar. Tujuan tes hasil belajar yaitu mengungkap keberhasilan seseorang dalam belajar. Tes hasil belajar berupa tes yang disusun secara terencana untuk mengungkap performasi maksimal subyek dalam menguasai bahan atau materi yang diajarkan.

\section{Motivasi Belajar}

Motivasi belajar didefinisikan sebagai keinginan atau dorongan untuk belajar (Sardiman, 2008). Motivasi adalah perubahan energi dalam diri seseorang yang ditandai dengan munculnya feeling dan didahului dengan tanggapan terhadap adanya tujuan. Motivasi belajar dapat timbul karena faktor intrinsik dan faktor ekstrinsik. Faktor intrinsik berupa hasrat dan keinginan berhasil serta dorongan kebutuhan belajar, harapan akan cita-cita. Faktor ekstrinsik berupa adanya penghargaan, lingkungan belajar yang kondusif dan kegiatan belajar yang menarik. Siswa yang memliki motivasi belajar tinggi cenderung memiliki prestasi belajar yang lebih baik dibandingkan dengan siswa yang motivasi belajarnya rendah. Hal ini dikarenakan oleh siswa yang memiliki motivasi belajar tinggi akan tekun belajar tanpa mengenal putus asa 
serta dapat mengesampingkan hal-hal yang dapat mengganggu kegiatan belajarnya. Jadi, motivasi belajar terkait dengan faktor psikis siswa. Motivasi belajar juga mempengaruhi keikutsertaan siswa dalam proses pembelajaran. Apabila motivasi belajar siswa tinggi, maka keikutsertaan siswa di dalam kelas juga tinggi misalnya keaktifan siswa, begitu pula sebaliknya.

\section{Kartu Soal}

Kartu soal adalah media pembelajaran sederhana yang didalamnya memuat soal-soal latihan dalam tingkatantingkatan tertentu serta melayani siswa sesuai dengan tingkat kemampuan intelektualnya sehingga kemampuan siswa dalam asas perbedaan individu lebih diperhatikan (Aisah, S., Ashari, H., \& R.Wakhid, 2013). Kartu soal menyediakan masalah-masalah yang dapat melatih keterampilan siswa di dalam memecahkan masalah sehingga siswa memiliki pemahaman/konsep yang kuat tentang bagaimana memecahkan suatu masalah.Peningkatan kemampuan pemecahan masalah siswa dalam kegiatan belajar diperlukan adanya soalsoal yang memenuhi kriteria soal pemecahan masalah.Soal-soal tersebut kemudian dituangkan ke dalam bentuk media pembelajaran berupa kartu soal.

\section{METODE}

Penelitian ini memiliki tujuan untuk mengetahui pengaruh penggunaan model pembelajaran Think Pair Square dan Think Pair Share terhadap hasil belajar dan motivasi belajar siswa kelas $X$ pada mata pelajaran TIK di SMA Negeri 1 Sukasada. Standar kompetensi yang digunakan dalam penelitian ini yaitu "Menggunakan Perangkat Lunak Pengolah Kata". Populasi penelitian ini adalah seluruh siswa kelas $X$ di SMA Negeri 1 Sukasada Tahun Ajaran 2015/2016 dan sampel penelitian ini yaitu kelas X1 sebagai kelas eksperimen 1 sebanyak 22 siswa, X3 sebagai kelas eksperimen 2 sebanyak 19 siswa dan X5 sebagai kelas kontrol sebanyak 19 siswa. Pada penelitian ini diberikan perlakuan yang berbeda terhadap ketiga kelas sampel. Kelas eksperimen 1 diberikan perlakuan berupa penerapan model pembelajaran Think Pair Square, kelas eksperimen 2 diberikan perlakuan berupa penerapan model pembelajaran Think Pair Share dan kelas kontrol diberikan perlakuan berupa penerapan model pembelajaran konvensional yaitu Direct Instruction. Desain penelitian yang digunakan adalah posttest only control group design. Rancangan ini dipilih karena selama melakukan eksperimen tidak memungkinkan mengubah kelas yang sudah ada. Terdapat 2 variabel dalam penelitian ini yaitu variabel bebas dan variabel terikat. Variabel bebas terdiri dari model pembelajaran Think Pair Share dan Think Pair Square serta veriabel terikat terdiri dari hasil belajar dan motivasi belajar. Gambar berikut ini merupakan tahapan penelitian yang dilakukan.

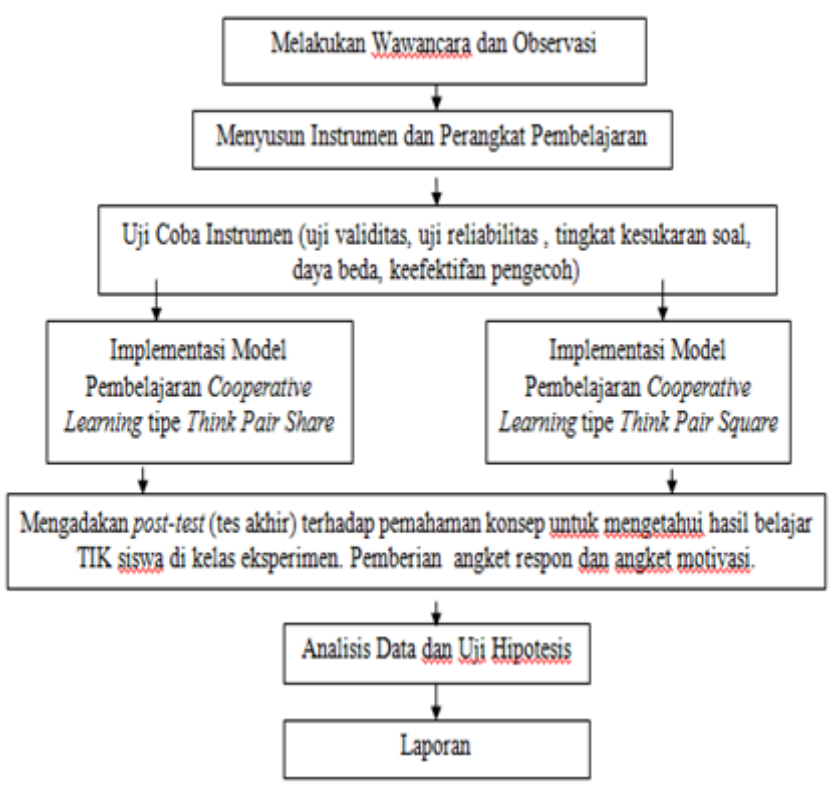

Gambar 1. Prosedur Penelitian

Metode pengumpulan data yang digunakan dalam penelitian ini adalah metode tes dan angket. Metode tes digunakan untuk mengetahui hasil belajar TIK siswa dengan menggunakan tes pilihan ganda (kognitif) dan tes unjuk kerja (psikomotor), sedangkan metode angket digunakan untuk mengetahui respon siswa dan motivasi belajar siswa terkait dengan penerapan model pembelajaran Think Pair Square dan Think Pair Share dalam proses pembelajaran. Sebelum diterapkan 
pada kelas sampel penelitian, instrumen terlebih dahulu akan dilakukan uji ahli maupun uji coba. Uji prasyarat yang digunakan dalam penelitian ini yaitu uji normalitas dilakukan untuk mengetahui sebaran data tersebut normal atau tidak normal terhadap hasil belajar TIK pada kelas eksperimen dan kelas kontrol. Selanjutnya uji homogenitas yang dilakukan untuk mengetahui apakah varians kelompok eksperimen dan kelompok kontrol homogen atau tidak homogen dan uji hipotesis dilakukan untuk mengetahui apakah hipotesis alternatif yang telah diajukan diterima atau ditolak dengan menggunakan rumus Anova Satu Jalur dengan uji lanjut $t$-Scheffe. Hipotesis I diuji menggunakan Anova Satu Jalur dengan hipotesis sebagai berikut.

Uji Hipotesis I:

HO : Tidak ada pengaruh yang signifikan penggunaan model pembelajaran Cooperative Learning tipe Think Pair Square, Think Pair Share dan Direct Instruction.

$\mathrm{Ha}$ : Terdapat pengaruh yang signifikan penggunaan model pembelajaran Cooperative Learning tipe Think Pair Square, Think Pair Share dan Direct Instruction.

Selanjutnya uji hipotesis II menggunakan uji lanjut $t$-Scheffe dengan hipotesis sebagai berikut.

Uji Hipotesis II:

HO : Tidak ada perbedaan rata-rata hasil belajar siswa yang menggunakan model pembelajaran Cooperative Learning tipe Think Pair Square, Think Pair Share dan Direct Instruction.

$\mathrm{Ha}$ : Terdapat perbedaan rata-rata hasil belajar siswa yang menggunakan model pembelajaran Cooperative Learning tipe Think Pair Square, Think Pair Share dan Direct Instruction.

Skor rata-rata angket respon dan motivasi belajar siswa didapatkan dengan membagi jumlah skor angket jawaban siswa dengan jumlah siswa. Penelitian ini tidak membandingkan variabel motivasi belajar siswa.

\section{HASIL DAN PEMBAHASAN \\ Hasil}

Data dari hasil pengukuran hasil belajar Teknologi Informasi dan Komunikasi (TIK) terhadap 22 siswa kelompok eksperimen 1 menunjukan bahwa skor tertinggi adalah 59 dan skor terendah adalah 45. Rata-rata atau Mean (M) posttest hasil belajar TIK yang dicapai pada siswa kelas eksperimen 1 sebesar 54,32 . Data dari hasil pengukuran hasil belajar Teknologi Informasi dan Komunikasi (TIK) terhadap 19 siswa kelompok eksperimen 2 menunjukan bahwa skor tertinggi adalah 56 dan skor terendah adalah 44.

Hasil posttest kelas eksperimen I yang menggunakan model pembelajaran Think Pair Square mendapatkan hasil sebanyak $95 \%$ berkategori sangat tinggi, sebanyak $5 \%$ berkategori tinggi, serta tidak ada yang tergolong kedalam kategori sedang, rendah, dan sangat rendah.

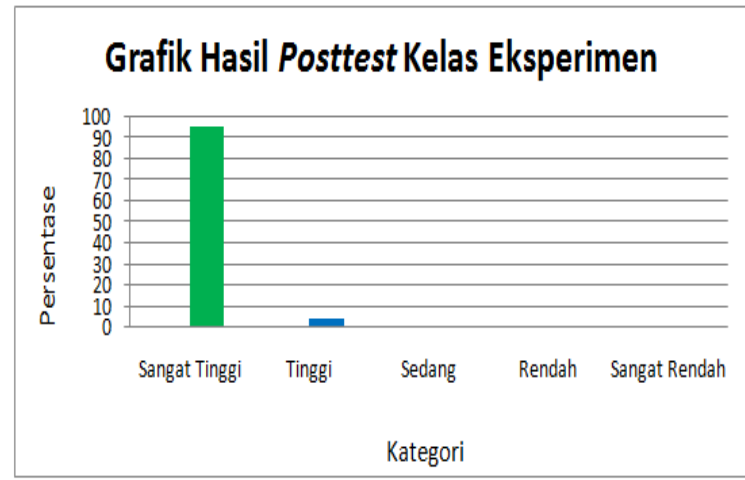

Gambar 2. Histogram hasil posttes model pembelajaran Think Pair Square

Hasil posttest kelas eksperimen II dengan model pembelajaran Think Pair Share mendapatkan hasil sebanyak $84 \%$ berkategori sangat tinggi, sebanyak $16 \%$ berkategori tinggi, serta tidak ada yang tergolong kedalam kategori sedang, rendah, dan sangat rendah. 


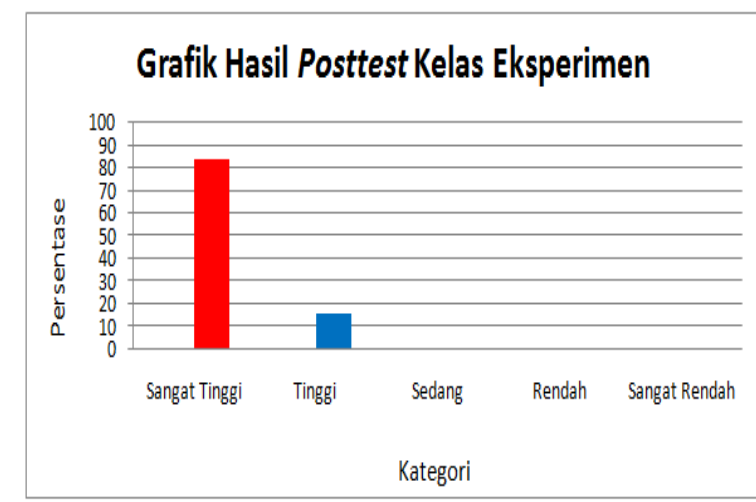

Gambar 3. Histogram hasil posttest model pembelajaran Think Pair Share

Hasil posttest kelas kontrol dengan model pembelajaran Direct Instruction sebanyak $16 \%$ berkategori sangat tinggi, sebanyak $68 \%$ berkategori tinggi, sebanyak $16 \%$ berkategori sedang, serta tidak ada yang berkategori rendah, dan sangat rendah.

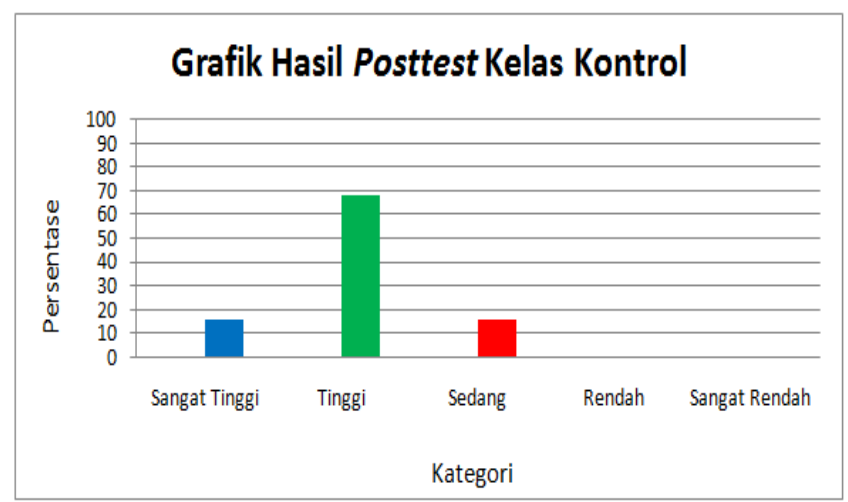

Gambar 4. Histogram hasil posttest model pembelajaran Direct Instruction

Rata-rata atau Mean (M) posttest hasil belajar TIK yang dicapai pada siswa kelas eksperimen 2 sebesar 49,11. Data dari hasil pengukuran hasil belajar Teknologi Informasi dan Komunikasi (TIK) terhadap 19 siswa kelompok kontrol menunjukan bahwa skor tertinggi adalah 49dan skor terendah adalah 35. Rata-rata posttest hasil belajar TIK untuk kelas kontrol sebesar 42,16.

Tabel 1. Rata-rata Hasil Belajar Siswa

\begin{tabular}{clcc}
\hline No & \multicolumn{1}{c}{ Kelompok } & Rata-rata \\
\hline 1 & $\begin{array}{l}\text { Kelompok } \\
\text { Pembelajaran Think Pair Square }\end{array}$ & Model \\
2 & $\begin{array}{l}\text { Kelompok } \quad \begin{array}{l}\text { Eksperimen } \\
\text { Pembelajaran Think Pair Share Model }\end{array} \\
\text { Kelompok Kontrol Model Pembelajaran } \\
3\end{array}$ & $\begin{array}{l}\text { Kirect Instruction } \\
\text { Diren }\end{array}$ \\
\hline
\end{tabular}

Perhitungan uji prasyarat normalitas dan homogenitas kelas eksperimen dan kelas kontrol memiliki data yang normal dan homogen, berdasarkan uji normalitas yang telah dilakukan diperoleh bahwa distribusi data dari ketiga kelas normal, dimana hasil perhitungan pada kelas eksperimen 1 memperoleh $\mathrm{X}^{2}$ hitung sebesar
4,148, kelas eksperimen 2 memperoleh $\mathrm{X}^{2}$ hitung sebesar 3,052 sedangkan pada kelas kontrol memperoleh $\mathrm{X}^{2}$ hitung sebesar 1,969 dengan $X^{2}$ tabel sebesar 5,991. Karena $X^{2}$ hitung dari ketiga kelas lebih kecil dari $\mathrm{X}^{2}$ tabel maka dapat dinyatakan bahwa distribusi data dari ketiga kelas tersebut normal.

Tabel 2. Hasil Uji Normalitas

\begin{tabular}{ccccc}
\hline No & Sampel & $\mathbf{X}_{\text {hitung }}\left(X_{h}^{2}\right)$ & $\mathbf{X}_{\text {tabel }}\left(X_{t}^{2}\right)$ & Keterangan \\
\hline 1 & Kelompok eksperimen I & 4,148 & 5,991 & Normal \\
2 & Kelompok eksperimen II & 3,052 & 5,991 & Normal \\
3 & Kelompok kontrol & 1,969 & 5,991 & Normal \\
\hline
\end{tabular}

Uji prasyarat selanjutnya yaitu melakukan uji homogenitas yang telah dilakukan dan diperoleh hasil bahwa varians antara kelas eksperimen dan kelas kontrol homogen, dimana diperoleh nilai $F_{\text {hitung }}$ sebesar 1,57 dengan $F_{\text {tabel }}$ sebesar 
2,25, karena nilai $F_{\text {hitung }}$ lebih kecil dari $F_{\text {tabel }}$ maka dapat dinyatakan bahwa varians dari ketiga kelas homogen.

Setelah diketahui bahwa sebaran data pada kelas eksperimen dan kelas kontrol normal dan homogen, maka dilakukan pengujian hipotesis menggunakan rumus Anova Satu Jalur dengan taraf signifikansi $5 \%$ dan $1 \%$, dimana dari perhitungan tersebut memperoleh $F_{\text {hitung }}$ sebesar 54,96 dengan $F_{\text {tabel }} 5 \%$ sebesar 3,17 dan $F_{\text {tabel }} 1 \%$ sebesar 5,01.

Tabel 3. Hasil Analisis Uji Hipotesis

\begin{tabular}{lccccc}
\hline & Sum of Squares & df & Mean Square & F & Sig. \\
\hline Between Groups & 1415.327 & 2 & 707.663 & 54.961 & .000 \\
Within Groups & 733.923 & 57 & 12.876 & & \\
Total & 2149.250 & 59 & & & \\
\hline
\end{tabular}

Karena $F_{\text {hitung }}$ lebih besar dari $F_{\text {tabel }}$ maka hipotesis alternatif yang telah diajukan diterima yang artinya terdapat pengaruh yang signifikan penggunaan model pembelajaran Cooperative Learning tipe Think Pair Square, Think Pair Share dan Direct Instruction. Karena $F_{\text {hitung }}$ signifikan, maka harus dilanjutkan dengan uji pasangan dengan $t$-Scheffe. Dari hasil perhitungan dilakukan 3 kali uji $t$-Scheffe dengan uji pasangan 1 yaitu model Think Pair Square dan Think Pair Share dengan thitung sebesar 4,64 dengan $F_{\text {tabel }}$ sebesar 4,1 maka hipotesis alternatif yang diajukan dapat diterima artinya terdapat perbedaan hasil belajar penggunaan model Think Pair Square dan Think Pair Share.

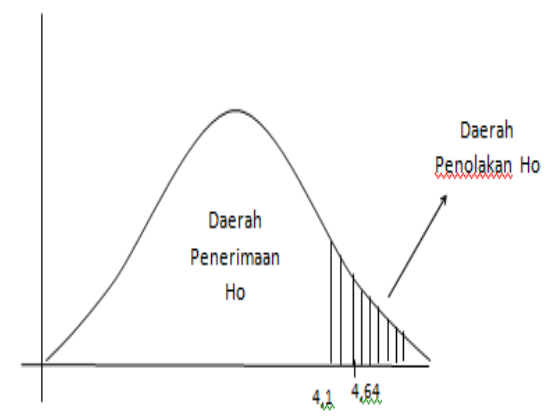

Gambar 5. Kurva uji satu arah model Think Pair Square dan Think Pair Share

Uji pasangan 2 yaitu model Think Pair Square dan Direct Instruction dengan $t_{\text {hitung }}$ sebesar 10,82 dengan $F_{\text {tabel }}$ sebesar 4,1 maka hipotesis alternatif yang diajukan dapat diterima artinya terdapat perbedaan hasil belajar penggunaan model Think Pair Square dan Direct Instruction.

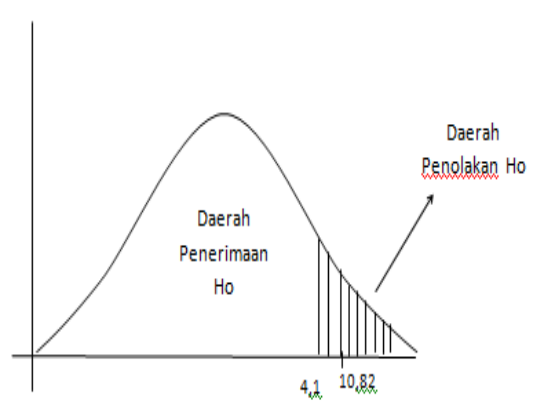

Gambar 6. Kurva uji satu arah model Think Pair Share dan Direct Instruction

Uji pasangan 3 yaitu model Think Pair Share dan Direct Instruction dengan $t_{\text {hitung }}$ sebesar 5,97 dengan $F_{\text {tabel }}$ sebesar 4,1 maka hipotesis alternatif yang diajukan dapat diterima artinya terdapat perbedaan hasil belajar penggunaan model Think Pair Share dan Direct Instruction.

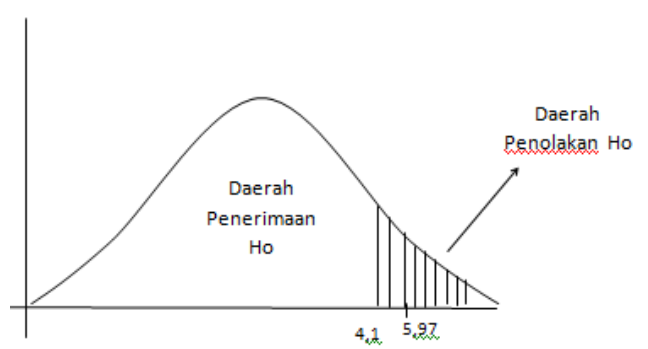

Gambar 7. Kurva uji satu arah model Think Pair Square dan Direct Instruction

Selanjutnya untuk menentukan model pembelajaran yang lebih baik dilihat dari rata-rata hasil belajar kelompok eksperimen dan kelompok kontrol. Berdasarkan rata-rata hasil belajar 
kelompok eksperimen dan kelompok kontrol maka dapat disimpulkan bahwa model pembelajaran Think Pair Square lebih baik daripada model pembelajaran
Think Pair Share dan Direct Instruction dengan rata-rata hasil belajar yang lebih tinggi 54,32 dari ketiga kelas tersebut.

Tabel 4. Rata-rata Hasil Belajar Siswa

\begin{tabular}{ccc}
\hline No & Kelompok & Rata-rata \\
\hline 1 & Model Pembelajaran Think Pair Square & 54,32 \\
2 & Model Pembelajaran Think Pair Share & 49,11 \\
3 & Model Pembelajaran Direct Instruction & 42,16 \\
\hline
\end{tabular}

Hasil analisis respon siswa terhadap proses pembelajaran dengan menerapkan model pembelajaran Think Pair Square dikumpulkan melalui angket respon yang mana respon siswa termasuk dalam kategori sangat positif. Diketahui sebanyak $86 \%$ siswa merespon sangat positif akan model pembelajaran Think Pair Square yang diterapkan dan 14\% siswa merespon positif.

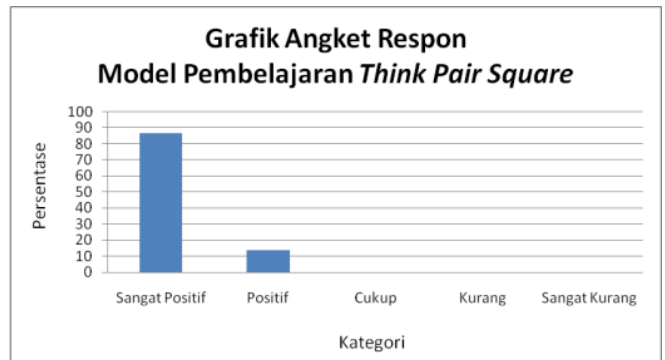

Gambar 8. Histogram Analisis Respon Model Pembelajaran Think Pair Square

Selanjutnya hasil analisis respon siswa terhadap proses pembelajaran yang menerapkan model pembelajaran Think Pair Share termasuk dalam kategori positif. Diketahui sebanyak 37\% siswa merespon sangat positif akan model pembelajaran Think Pair Share yang diterapkan, 58\% siswa merespon positif dan $5 \%$ siswa merespon cukup positif.

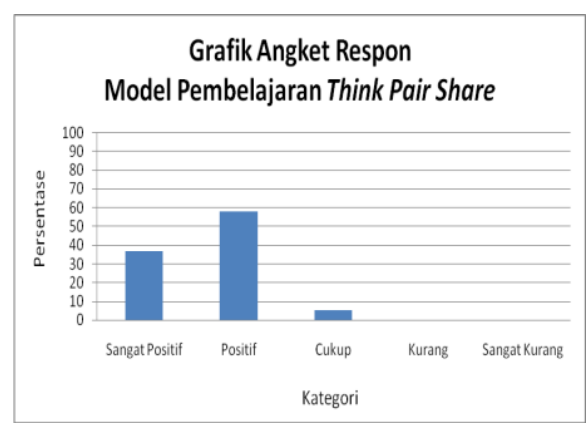

Gambar 9. Histogram Analisis Respon Model Pembelajaran Think Pair Share
Hasil analisis motivasi belajar siswa kelompok eksperimen dan kelompok kontrol dikumpulkan melalui angket motivasi. Analisis motivasi belajar siswa kelompok eksperimen 1 yang diberlakukan model pembelajaran Think Pair Square termasuk dalam kategori sangat tinggi. Terdapat sebanyak $86 \%$ siswa yang memiliki tingkat motivasi belajar sangat tinggi akan model pembelajaran Think Pair Square yang diterapkan dan $14 \%$ siswa yang memiliki tingkat motivasi belajar tinggi.

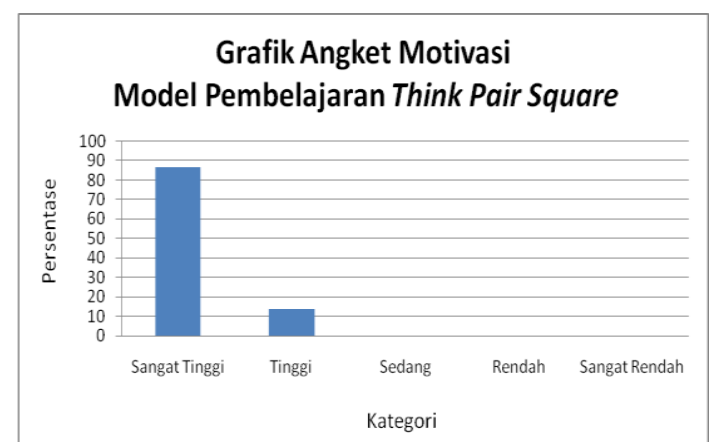

Gambar 10. Histogram Analisis Motivasi Belajar Model Pembelajaran Think Pair Square

Kemudian analisis motivasi belajar siswa kelompok eksperimen 2 yang diberlakukan model pembelajaran Think Pair Share termasuk dalam kategori sangat tinggi. Terdapat sebanyak 53\% siswa yang memiliki tingkat motivasi belajar sangat tinggi akan model pembelajaran Think Pair Share yang diterapkan, $42 \%$ siswa yang memiliki tingkat motivasi belajar tinggi dan 5\% siswa yang memiliki tingkat motivasi belajar sedang. 


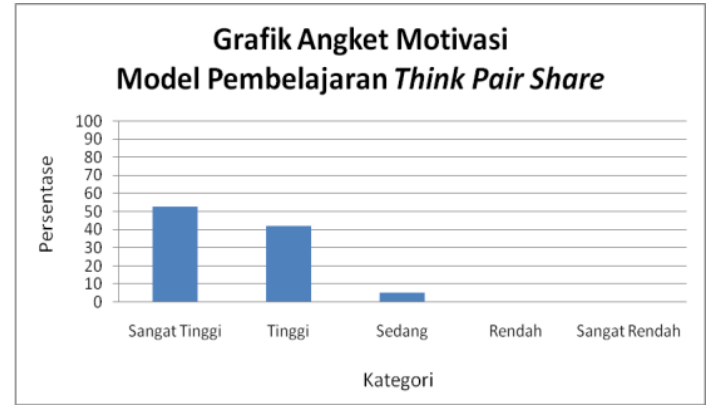

Gambar 11. Histogram Analisis Motivasi Belajar Model Pembelajaran Think Pair Share

Selanjutnya motivasi belajar siswa kelompok kontrol dengan penerapan model pembelajaran konvensional yaitu model pembelajaran Direct Instruction termasuk dalam kategori rendah. Terdapat sebanyak $11 \%$ siswa yang memiliki tingkat motivasi belajar tinggi akan model pembelajaran Direct Instructionyang diterapkan, 32\% siswa yang memiliki tingkat motivasi belajar sedang dan $58 \%$ siswa yang memiliki tingkat motivasi belajar rendah.

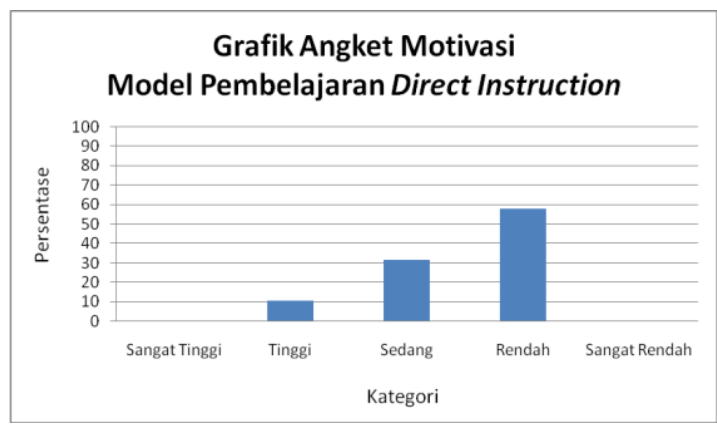

Gambar 12. Histogram Analisis Motivasi Belajar Model Pembelajaran Direct Instruction

\section{Pembahasan}

Model pembelajaran Think Pair Square memiliki rata-rata hasil belajar yang lebih tinggi disebabkan karena model pembelajaran Think Pair Square merupakan model pembelajaran yang bersifat kooperatif atau proses pembelajaran secara berkelompok. Dalam tahapan pembelajaran ini, siswa dituntut menyelesaikan suatu permasalahan dengan cara diskusi berpasangan dengan membentuk kelompok pasangan yang terdiri dari 2 orang. Dalam proses pembelajaran, ada kelompok yang telah berhasil menyelesaikan masalah dan ada kelompok yang masih belum berhasil menyelesaikan permasalahan yang diberikan. Langkah selanjutnya dalam proses pembelajaran ini yaitu masingmasing kelompok berpasangan akan dipasangkan kembali dengan kelompok pasangan lainnya sehingga membentuk kelompok yang terdiri dari 2 pasang kelompok berpasangan. Pada tahap ini kelompok pasangan yang berhasil menyelesaikan permasalahan akan bekerja sama dan membantu kelompok pasangan yang belum bisa menyelesaikan masalah sehingga akhirnya seluruh siswa dapat menyelesaikan permasalahan yang diberikan. Model pembelajaran ini memudahkan guru memantau proses pembelajaran selain karena jumlah kelompok yang dibentuk sedikit, kelompok yang masih belum paham akan dibantu dengan kelompok yang sudah paham sehingga peran guru dalam membimbing kelompok yang mengalami masalah pada proses pembelajaran tidak terlalu banyak. Pada akhir proses pembelajaran ini mendapatkan hasil bahwa seluruh kelompok dapat menyelesaikan permasalahan dengan baik.

Proses pembelajaran dengan menerapkan model pembelajaran Think Pair Share lebih baik dibandingkan dengan konvensional jika dilihat dari hasil belajar. Hal ini disebabkan karena model pembelajaran Think Pair Share juga merupakan model pembelajaran kooperatif yang menuntut siswa bekerja sama dalam menyelesaikan suatu permasalahan. Tahap model pembelajaran ini membentuk kelompok berpasangan yang terdiri dari 2 orang siswa dan masing-masing kelompok akan mendiskusikan dan menyelesaikan permasalahan yang diberikan. Dalam proses pembelajaran model pembelajaran Think Pair Share, kelompok yang diawasi oleh guru jumlahnya lebih banyak dari kelompok yang dibentuk pada proses pembelajaran model pembelajaran Think Pair Square sehingga apabila banyak kelompok yang mengalami masalah, maka peran guru dalam membimbing kelompok siswa tersebut jadi banyak. Pada akhir 
proses pembelajaran ini mendapatkan hasil bahwa pada beberapa pertemuan ada beberapa kelompok yang belum dapat menyelesaikan permasalahan dengan baik.

Proses pembelajaran konvensional dengan menerapkan model pembelajaran Direct Instruction masih mencapai hasil belajar yang rendah karena pada penelitian ini dikarenakan model pembelajaran Direct Instruction menuntut siswa menyelesaikan permasalahan yang diberikan secara individu. Pada proses pembelajaran ini pula dilihat bahwa siswa masih bingung dan kurang jelas dalam memahami penjelasan guru didepan kelas sehingga ketika proses praktikum, masih banyak siswa mengalami masalah dalam menyelesaikan permasalahan yang diberikan oleh guru walaupun sebelumnya sudah dijelaskan materi yang akan dibahas pada pertemuan itu. Pada proses pembelajaran ini peran guru dalam membimbing siswa lebih banyak dibandingkan dengan penerapan model Think Pair Share dan Think Pair Square. Pada akhir proses pembelajaran ini, terdapat masih banyak siswa yang belum menyelesaikan permasalahan yang diberikan dengan baik selain karena siswa masih bingung mencari solusi, model pembelajaran ini juga sering kekurangan waktu dalam menyelesaikan permasalahan yang diberikan.

\section{SIMPULAN DAN SARAN}

Berdasarkan rumusan masalah, tujuan penelitian, pengajuan hipotesis dan analisis data penelitian, maka dapat ditarik beberapa simpulan sebagai berikut : (1) adanya pengaruh yang signifikan penggunaan model pembelajaran Cooperative Learning tipe Think Pair Square, Think Pair Share dan Direct Instruction terhadap hasil belajar TIK untuk materi Microsoft Office Word 2007 siswa kelas X SMA N 1 Sukasada tahun pelajaran 2015/2016. (2) terdapat rat-rata hasil belajar yang lebih tinggi pada siswa yang yang menggunakan model pembelajaran Cooperative Learning tipe Think Pair Square dibandingkan dengan model pembelajaran Cooperative Learning tipe Think Pair Share pada mata pelajaran
TIK kelas $X$ SMA $N 1$ Sukasada tahun pelajaran 2015/2016. (3) terdapat peningkatan motivasi siswa terhadap proses pembelajaran menggunakan model pembelajaran Think Pair Share dan Think Pair Square pada siswa kelas $X$ SMA N 1 Sukasada. (4) terdapat respon yang sangat positif dari siswa dalam proses pembelajaran menggunakan model pembelajaran Think Pair Square dan Think Pair Share.

Hasil penelitian yang diperoleh, maka peneliti memberikan saran-saran sebagai berikut guna meningkatkan kualitas pembelajaran TIK: (1) bagi Guru: Hasil penelitian ini menunjukkan bahwa siswa yang belajar dengan menggunakan model pembelajaran Think Pair Square dan Think Pair Share secara signifikan memperoleh hasil belajar TIK yang lebih baik, motivasi belajar yang sangat tinggi dan respon siswa yang positif daripada siswa yang menggunakan model pembelajaran Konvensional. Oleh karena itu, penulis menyarankan kepada guru pengajar untuk menerapkan model pembelajaran Think Pair Square dan Think Pair Share pada proses pembelajaran selanjutnya. (2) bagi Siswa: Hasil belajar yang meningkat dan motivasi belajar yang sangat tinggi dalam proses pembelajaran sebaiknya dijaga dan dipertahankan dalam proses pembelajaran selanjutnya baik pada mata pelajaran TIK maupun pelajaran yang lain. (3) bagi Peneliti: Dalam menentukan kelas untuk penelitian sebaiknya dipastikan jumlah siswa dari awal pertemuan proses pembelajaran hingga akhir pertemuan benar-benar sesuai dan tidak ada siswa yang pindah sekolah atau berhenti sekolah pada pertengahan pertemuan karena akan berdampak pada kurangnya kelompok yang dibentuk secara berpasangan maupun kelompok berempat yang terdiri dari 2 pasang.

\section{DAFTAR PUSTAKA}

Trianto. (2009). Model-model Pembelajaran Inovatif Berorientasi Konstruktivistik. Jakarta: Prestasi Pustaka Publiser. 
Komalasari, K. (2010). Pembelajaran Konstektual. Bandung: Refika Aditama.

Slavin, R. E. (2009). Cooperative Learning Teori, Riset dan Praktik. Bandung: Nusa Media.

Primandari, A. H. (2010). Upaya Meningkatkan Kemampuan Pemecahan Masalah Siswa Kelas VIIIA Smp N 2 Nanggulan Dalam Pembelajaran Matematika Pokok Bahasan Bangun Ruang Menggunakan Model Pembelajaran Kooperatif Tipe Think Pair Square. Universitas Negeri Yogyakarta.

Kusuma, F. W., \& Aisyah, M. N. (2012). Implementasi Model Pembelajaran Kooperatif Tipe Think Pair Share Untuk Meningkatkan Aktivitas Belajar Akuntansi Siswa Kelas XI IPS 1 SMA Negeri 2 Wonosari Tahun Ajaran 2011/2012. UNY.

Aisah, S., Ashari, H., \& R.Wakhid. (2013). Penggunaan Model Pembelajaran Cooperative Learning Tipe Think Pair Square Berbantuan Kartu Soal Untuk Meningkatkan Aktivitas Belajar Siswa Kelas VII B SMP Negeri 5 Purworejo. Universitas Muhammadiyah Purworejo.

Slameto. (2003). Belajar dan Faktor-faktor yang Mempengaruhinya. Jakarta: Rineka Cipta.

Suwatra. (2007). Modul Belajar dan Pembelajaran. Universitas Pendidikan Ganesha.

Trianto. (2009). Mendesain Model Pembelajaran Inovatif-Progresif. Jakarta: Kencana Prenada Media Group.

Suherman, E. (2001). Common textbook: Strategi Pembelajaran Matematika Kontemporer. Bandung: JICA-UPI.

Dewi. (2014). Pengaruh Penerapan Model Pembelajaran TPS(Think, Pair, Share) Berbantuan Media Audio Visual Terhadap Hasil Belajar IPS
Kelas V Gugus I Gusti Ngurah Rai Penatih. UNDIKSHA.

Trianto. (2010). Model-model Pembelajaran Inovatif Berorientasi Konstruktivistik. Jakarta: Prestasi Pustaka Publiser.

Dorsey, Jackie. (2009). "Think, Pairs, Square, Share". Disajikan di http://web.monroecc.edu/tcc.

Diakses tanggal 6 Oktober 2015.

Wraspana. (2013). Pengaruh Model Pembelajaran Kooperatif Tipe Group Investigation Terhadap Hasil Belajar Fisika Siswa Kelas X SMA N 1 Sukasada Tahun Pelajaran 2012/2013. UNDIKSHA.

Sardiman. (2008). Interaksi dan Motivasi Belajar Mengajar. Jakarta: Grafindo.Suparno, P. 1997. Filsafat Konstruktivisme dalam Pendidikan. Yogyakarta: Kanisius 